\section{Fascinerende reise gjennom livet}

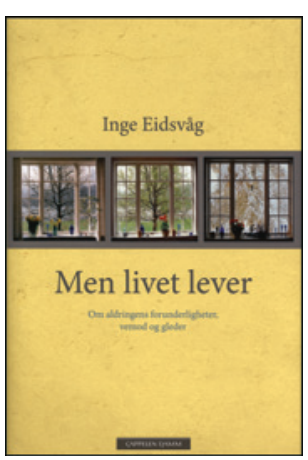

\section{Spenning i kjent Damhaug-stil}

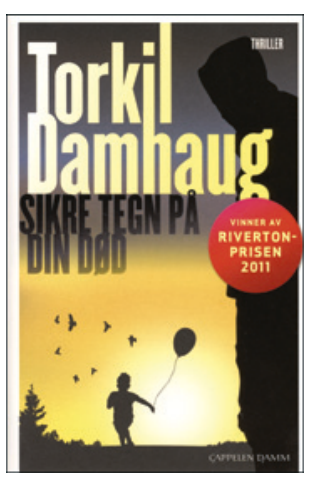

\author{
Torkil Damhaug \\ Sikre tegn på din død
}

408 s. Oslo: Cappelen Damm, 2013.

Pris NOK 379

ISBN 978-82-02-42131-1
Denne oversikten over synet på alderdommen og holdningen til gamle mennesker fra antikken og frem til i dag viser at det til tider har eksistert et positivt syn på å bli gammel, mens det til andre tider har vært en negativ oppfatning av tilstanden.

Forfatteren benytter seg av et imponerende antall uttalelser og sitater fra kjente filosofer, historikere, diktere og vismenn som beskriver hvordan økonomi, kulturelle og sosiale forhold, alderssammensetning og teknologiutvikling har påvirket gamle menneskers status. Temaet «alderdom» har skapt heftig debatt gjennom historien. I antikken sto f.eks. Platon og hans elev Aristoteles for forskjellig syn på hvordan alderen påvirker nytteverdien av et menneske. Platon mente at det er menneskets karakter som teller, ikke alderen. Aristoteles derimot lovpriste ungdommens fortreffelighet.

Først i det 20. århundre, med stigende levealder, er det blitt økt oppmerksomhet omkring alderdommens muligheter og ressurser, men det negative synet på de gamle er seiglivet. Knut Hamsun tilba ungdommen og snakket negativt om de gamle nesten hele sitt liv. At han produserte mange av sine beste bøker da han var over 80 år, ble et kraftig indisium på at han kanskje burde ha moderert seg en smule tidligere i livet.

Eidsvåg påpeker at det ikke gir status å være gammel. Lover, regler og praksis i Norge blokkerer eldre menneskers livsutfoldelse og fører til at mange gamle blir inaktive. Dette bør endres. Praktiske erfaringer fra arbeidslivet og moderne vitenskap taler til fordel for Platons syn. Det er menneskenes egenskaper som teller, ikke kronologisk alder.

Boken er i stor grad preget av biografiske innslag fra forfatterens liv. Han viser til «klodens» kritiske tilstand hvor mangelen på nødvendig politisk handling, uheldig kløft mellom fattig og rik og inhuman behandling av innvandrere og andre vanskeligstilte grupper, er påtrengende. I hans etterlysning av sterkere engasjement for endring setter han også søkelyset på hvordan vi eldre bidrar til å forbedre våre samfunn og fremtid. Han stiller spørsmålet om vi i altfor stor grad tenker på oss selv og svikter kommende generasjoner.

I den siste delen gir forfatteren oss råd om hva som kan gjøre våre liv rikere. Som ellers i boken bruker han kjente filosofer og diktere som hjelpere - en kombinasjon som fungerer godt. Boken avsluttes med korte utdrag fra poesiens verden, bl.a. av Henrik Ibsen, Bjørnstjerne Bjørnson, Knut Hamsun og Vargas Llosa.

Jeg anbefaler boken på det varmeste, og den passer for alle.
Lege Torkil Damhaug har i løpet av de siste årene etablert seg som en av Norges ypperste krimforfattere. I 2011 vant han Rivertonprisen for Ildmannen. Nå er han ute med en ny kriminalroman, eller psykologisk thriller - boken kan fint passe i begge sjangre.

Boken er skrevet etter samme oppskrift som flere av Damhaugs tidligere utgivelser. Der en typisk kriminalroman gjerne følger en etterforsker med personlige problemer gjennom oppklaringen av ett eller flere drap, velger Damhaug å nøste seg frem til løsningen på drapsgåten ved å følge ulike karakterer som er involvert i handlingen på forskjellig vis. Denne gangen fortelles historien gjennom patolog og tidligere rettsmedisiner Jenny Plåterud, hennes nyforelskede sønn Sigurd og den iranske flyktningen og portøren Arash. Alle blir på ulikt vis innblandet når en pasient blir funnet myrdet i kjelleren på Ahus.

Mye av handlingen foregår i legemiljøet på Ahus, og det er nok av medisinske detaljer som får legeleseren til å føle seg på hjemmebane. Etterforskeren Roar Horvath, som Damhaugs lesere vil gjenkjenne fra tidligere bøker, dukker opp i en birolle også i denne historien. I kjent Damhaug-stil dukker det også opp en del psykiatriske diagnoser underveis.

Forfatterens skrivestil og psykologiske interesse og innsikt innebærer at leseren tas med dypt inn i hovedpersonenes sjelsliv, og mange ganger langt vekk fra det som egentlig er relevant for selve kriminalhistorien og handlingen. Dette gjør at spenningskurven kan bli litt slapp innimellom. Man kommer et stykke ut i boken før den blir vanskelig å legge fra seg. Historien er nokså innfløkt og krever konsentrasjon, og av og til må man bla litt tilbake for å sjekke hva som egentlig har skjedd. Noen vil kanskje synes det blir litt mye av det gode. Og er alle trådene egentlig nøstet opp når jeg lukker boken? Ikke lett å si, jeg er fortsatt litt usikker på hvordan alt hang sammen. Men det kan jeg leve med - boken var underholdende nok og er et godt alternativ for den som ønsker seg en litt annerledes krim.

\section{Hanne Støre Valeur}

Tidsskriftet 